\title{
POLITIK PENGELOLAAN KARST SANGKULIRANG- MANGKALIHAT: NONGOVERNMENTAL ORGANIZATION DAN AGENDA KELESTARIAN LINGKUNGAN
}

\author{
Etha Pasan
}

\begin{abstract}
This research try to describe how local NGO in East Kalimantan, Jatam (Mining Advocacy Network) and Walhi (Friends of the Life) pursue their interest in the politics of environmental management in Sangkulirang-Mangkalihat Karst Area in East Kutai and Berau Regency in East Kalimantan Province. How do they strive for their interest? What kind of strategy they deploy? And why? The result shows that there are several strategies that Jatam and Walhi use. They are: 1) Protest, 2) Seminar/FGD, and 3) Campaign. Those strategies are influenced by internal and external factors. For the internal factors, both Jatam and Walhi's structure of organization creates possibilities to collaborate with other party with the same agenda to achieve the goal. The second internal factor is the funding. Is is widely known that local NGO in East Kalimantan, especially those who strive for environmental protection lack the financial resources to fund their agenda. Both Jatam and Walhi's financial resources are relatively small compared to the resources of related actors such as the Government and corporations. With such conditions, street protests, seminar and campaign become the rational instruments to be deployed. The last is external factor that considers the social and political context of East Kalimantan society that make them choose those strategies.
\end{abstract}

Keywords: NGO, Exploitation, Strategy, Karst SangkulirangMangkalihat 


\section{Pendahuluan}

Posisi NGO (Non-Governmental Organization) dalam khazanah keilmuan Hubungan Internasional dewasa ini semakin signifikan (Betsill \& Corell, 2008:4). Hal ini bias diidentifikasi dengan melihat banyaknya studi yang dilakukan untuk mempelajari karakteristik, kapabilitas dan peran NGO dalam peta politik global, meskipun peran NGO juga sangat kentara pada level politik nasional dan lokal. Signifikansi posisi NGO dalam hubungan internasional tidak terlepas dari transformasi besar yang merubah hampir setiap sendi- sendi tatanan hubungan internasional yang ada.

Transformasi besar itu seringkali dikaitkan dengan globalisasi. Efek dari globalisasi adalah semakin kompleks serta dinamisnya hubungan internasional kontemporer disebabkan oleh munculnya aktor-aktor non-negara yang memiliki kepentingan-kepentingan yang berbeda serta keterkaitannya dengan isu-isu baru yang menjadi unsur pembentuk maupun sasaran proyeksi kepentingan aktor-aktor tersebut.

Salah satu isu yang muncul ke permukaan dalam kajian HI adalah isu degradasi lingkungan hidup. Secara resmi, isu lingkungan hidup mulai menjadi perhatian dalam hubungan internasional adalah ketika dilaksanakannya United Nations Conference on the Human Environment yang dilaksanakan di Stokholm pada 1972. Dalam konferensi tersebut mulai diperbincangkan tentang interaksi manusia dengan alam, di mana sebelumnya aktivitas manusia (dan juga negara-negara didunia) cenderung abai akan keberlangsungan lingkungan 
hidup seperti polusi, hujan asam, deforestasi, kekeringan, menipisnya lapisan ozon dan banyak permasalahan lingkungan lainnya. Selepas Konferensi Stokholm, berbagai upaya global dalam menangani isu ini berlanjut dengan dibentuknya berbagai konferensi dan kesepakatan internasional terkait dengan isu ini.

Posisi NGO dalam isu ini sangatlah penting. Sedari awal, NGO memainkan peran sentral dalam mengemukakan wacana degradasi lingkungan ini pada masyarakat internasional. Mereka juga sangat aktif dalam kegiatan pelestarian dan proteksi lingkungan yang dalam banyak kasus berseberangan dengan kebijakan nasional suatu negara yang ingin mengamankan kepentingan ekonominya. Konflik seringkali terjadi, namun terdapat pula kasus-kasus dimana NGO dan otoritas negara bekejasama untuk memecahkan permasalahan lingkungan hidup ini.

Fenomena tersebut merupakan fenomena global yang terjadi di mana-mana baik di negara-negara maju maupun negara berkembang dan negara miskin. Dinamika politik yang terjadi dan tarik-menarik kepentingan antar aktor dalam isu lingkungan hidup sangat menentukan bagaimana kemudian pengelolaan lingkungan itu dijalankan dan berujung pada keberlangsungan lingkungan itu sendiri. Disinilah menariknya kajian tentang NGO dan lingkungan hidup dalam diskursus HI di mana terdapat perbedaan antara karakteristik, misi, metode, kapabilitas, dan pola aliansi antar NGO yang beroperasi di negara maju, berkembang dan miskin serta isu spesifik yang mereka perjuangkan. 
Sebagaimana yang terjadi pada skala global, hal yang sama juga terjadi di Provinsi Kalimantan Timur, Indonesia, salah satunya adalah isu tentang pengelolaan ekosistem Karst Sangkulirang-Mangkalihat yang terletak di Kabupaten Kutai Timur dan Kabupaten Berau. Secara umum, karst adalah daerah yang memiliki bentang alam dan pola hidrologi khusus yang terbentuk dari kombinasi sifat batuan yang memiliki tingkat kelarutan tinggi dan porositas sekunder yang berkembang dengan baik (Paripurno, 2017:73-95).

Provinsi Kalimantan Timur sendiri merupakan salah satu provinsi yang memiliki hamparan batuan karbonat atau batu gamping terluas di Indonesia. Menurut data dari Pusat Pengendalian Pembangunan Ekoregion Kalimantan atau P3EK terdapat setidaknya $35.692 .50 \mathrm{Km}^{2}$ ekosistem karst yang ada di Kalimantan Timur atau dengan kata lain 28\% dari luas daratan di provinsi ini adalah kawasan karst. Dari penelitian yang sama juga didapatkan fakta bahwa sebagian kawasan karst dan batu gamping di Kalimantan Timur berada di atas kawasan hutan (Widyaningsih, 2017:5).

Salah satu kawasan karst yang paling banyak dikenal oleh masyarakat Kalimantan Timur adalah kawasan karst Sangkulirang-Mangkalihat. Kawasan ini memiliki luas $18.676,76 \mathrm{Km}^{2}$ di mana terdapat 105.000 penduduk yang tersebar di 111 desa dan 13 kecamatan yang menggantungkan hidupnya pada keberlangsungan ekosistem karst ini. Sebagai sumber air tawar utama, kawasan karst SangkulirangMangkalihat merupakan hulu dari 5 sungai besar di kawasan tersebut. Selain nilai ekologis, kawasan ini juga memiliki nilai 
budaya, ekonomi dan keanekaragaman hayati yang tinggi. Terdapat lukisan, artefak, kuburan, dan peninggalanpeninggalan pra-sejarah yang ada di 37 goa di kawasan ini, sehingga membuat pemerintah mengusulkan kawasan ini sebagai salah satu warisan dunia ke UNESCO. Untuk nilai ekonomi, kawasan karst Sangkulirang-Mangkalihat merupakan penghasil utama sarang burung walet serta memiliki destinasi wisata yang indah seperti Labuan Cermin. Di kawasan ini pula hidup 120 spesies burung, 200 spesies serangga dan atropoda, 400 spesies flora dan 50 spesies ikan serta menjadi habitat utama dari orangutan Kalimantan (pongo pygmaeus morio) (Salas et.al, 2005:15-23; Marshall et.al, 2017: 212-219; TNC, 2018:2).

Dengan nilai ekologis, budaya, ekonomi serta keanekaragaman hayati yang tinggi, sudah seharusnya kawasan karst Sangkulirang-Mangkalihat ini dilindungi oleh pemerintah baik pemerintah pusat maupun provinsi. Namun kenyataannya pemerintah provinsi Kalimantan Timur justru menerbitkan izin usaha secara masif untuk beroperasi di kawasan tersebut. Tercatat ada 217 izin usaha pertambangan dengan luas 9.057,32 $\mathrm{Km}^{2}$, 14 perusahaan yang bergerak di bidang pertambangan bahan semen dan pabrik semen dengan luas 1.259,93 $\mathrm{Km}^{2}, 41$ perusahaan yang mengantongi IUPHHKHT dengan luas 4.117,14 Km², 92 perusahaan yang mengantongi IUPHHKHA dengan luas $7.210,75 \mathrm{Km}^{2}$ dan 230 perusahaan yang mengantongi izin usaha perkebunan dengan luas $3.011,61 \mathrm{Km}^{2}$ (Widyaningsih, 2017:10). 
Pemerintah memang telah mengeluarkan regulasi yang mengatur tentang perlindungan ekosistem karst SangkulirangMangkalihat baik secara umum maupun khusus seperti Undang- Undang No.32 Tahun 2009 tentang Perlindungan dan Pengelolaan Lingkungan Hidup, Peraturan Pemerintah No. 26 tahun 2008 tentang Rencana Tata Ruang Wilayah Nasional, Peraturan Presiden No. 3 tahun 2012 tentang Rencana Tata Ruang Pulau Kalimantan, Peraturan Menteri ESDM No. 17 tahun 2012 tentang Penetapan Kawasan Bentang Alam Karst, Peraturan Gubernur Provinsi Kalimantan Timur No. 67 tahun 2012 tentang Perlindungan dan Pengelolaan Ekosistem Karst Sangkulirang-Mangkalihat di Kabupaten Berau dan Kutai Timur, serta Peraturan Daerah Provinsi Kalimantan Timur No.

1 tahun 2016 tentang Rencana Tata Ruang Wilayah Provinsi Kalimantan Timur tahun 2016-2036. Meski demikian, regulasi tersebut dianggap tidak cukup mampu untuk menjaga kelestarian karst Sangkulirang-Mangkalihat karena memuat perbedaan penetapan luasan ekosistem karst yang dimaksud dan abai terhadap asas kehati-hatian dalam menjaga ekosistem terutama pada Pergub Kaltim No. 67 tahun 2012 dan Perda Provinsi Kaltim No. 1 tahun 2016 yang memuat celah bagi ekploitasi karst untuk kepentingan bisnis.

Hal inilah yang kemudian memantik reaksi dari berbagai elemen masyarakat dan NGO lokal untuk menentang komersialisasi dan eksploitasi kawasan karst SangkulirangMangkalihat. Beberapa diantara mereka adalah Aliansi Masyarkat Peduli Karst Kaltim (AMPKK), Jatam (Jaringan Advokasi Tambang), dan Walhi (Wahana Lingkungan Hidup 
Indonesia). Mereka berpendapat bahwa eksploitasi karst Sangkulirang-Mangkalihat akan mendatangkan bencana besar baik secara ekologis maupun sosial dan ekonomi.

\section{Kerangka Teoritis : Konsep NGO}

Organisasi Non Pemerintah atau Non-Governmental Organization (NGO) secara umum merujuk pada lembaga atau institusi yang dibentuk oleh masyarakat sipil tanpa ada campur tangan atau keterkaitan dengan negara. Selain itu NGO juga biasanya dibentuk dengan tujuan-tujuan khusus yang menjadi alasan mengapa mereka didirikan. Setidaknya, NGO memiliki 3 karakteristik utama yakni: 1) tidak dibentuk oleh negara, 2) bergerak dalam dan memiliki kepedulian terhadap bidang yang spesifik, 3) memiliki nilai/tujuan yang independen dari campur tangan negara (Betsill \& Corell, 2008:4).

Dalam literatur HI, NGO yang menjalankan aktivitasnya pada tingkat global disebut sebagai International NonGovernmental Organization (INGO). Sebagaimana yang telah disinggung sebelumnya, posisi NGO dalam politik kontemporer tidak bisa lagi dianggap sebagai pelengkap dan marjinal. Bahkan dalam beberapa kasus, NGO memainkan peran penting dalam pengidentifikasian serta penyelesaian masalah atau isu-isu besar yang menjadi perhatian masyarakat dunia (Brown, Ebrahim \& Batliwala, 2011:1098-1108).

Brown, Ebrahim dan Batliwala menyebutkan bahwa dalam mencapai tujuannya NGO melakukannya melalui berbagai pola yang mereka sebut sebagai pola artikulasi kepentingan NGO. 
Setidaknya Brown dkk. mengidentifikasi 5 pola artikulasi kepentingan NGO yakni: 1) Pola Kesatuan, 2) Pola Federasi, 3) Pola Konfederasi, 4) Pola Jaringan dan 5) Pola Dukungan.

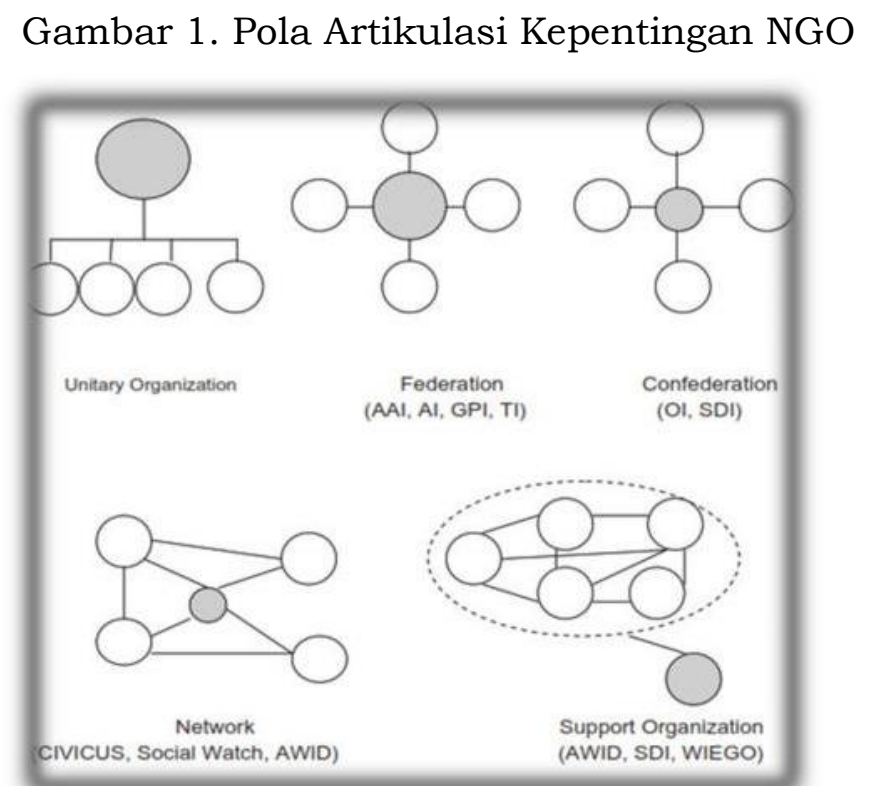

Sumber: L.David Brown, Alnoor Ebrahim and Srilatha Batliwala.

Governing International Advocacy NGOs. No. 06 Vol. 40. pp-1098-1108

Pola kesatuan memiliki ciri bahwa pengambilan keputusan dan distribusi sumber daya organisasi dilakukan oleh struktur yang paling atas atau dapat disebut sebagai sekretariat pusat. Pola federasi di sisi lain merupakan gabungan antara berbagai unit yang membentuk suatu organisasi besar yang kemudian dikomando oleh sekretariat pusat, namun kewenangan sekretariat pusat terhadap unitnya tidak sebesar pada pola kesatuan. Pola konfederasi hampir serupa dengan pola federasi namun yang membedakannya adalah sekretariat pusat tidak memiliki kewenangan yang lebih besar 
dibandingkan dengan unit sehingga memiliki kekuasaan yang terbatas. Pola jaringan merupakan gabungan organisasi yang berbagi nilai, informasi dan tujuan bersama, dan biasanya bersifat adhoc. Terakhir adalah pola dukungan di mana organisasi berperan sebagai pendukung yang berupaya untuk melobi aktor-aktor penting bagi pencapaian tujuan.

Pola artikulasi kepentingan pada akhirnya akan menentukan bagaimana strategi advokasi yang akan dilakukan oleh setiap organisasi. Berikut merupakan beberapa strategi dan target NGO.

Gambar 2. Strategi dan Target Advokasi NGO



Sumber: L. David Brown, Alnoor Ebrahim and Srilatha Batliwala. Governing International Advocacy NGOs. No. 06 Vol. 40.

$$
\text { pp-1098-1108 }
$$

Sebagaimana diterangkan pada tabel diatas, setidaknya ada dua strategi dari advokasi NGO dalam pencapaian 
tujuannya yakni dengan bekerjasama atau melawan. Tentu saja bekerjasama dalam konteks ini adalah bekerjasama dengan pihak pemerintah/pihak lain yang menghalangi tujuan mereka dengan harapan bisa merubah posisi serta pandangan mereka sehingga tercipta keselarasan kepentingan. Sebaliknya strategi lainnya adalah melawan.

\section{Pembahasan}

Penelitian ini bertujuan untuk melihat dinamika politik yang terjadi terkait dengan pengelolaan kawasan Karst Sangkulirang- Mangkalihat di Kalimantan Timur. Dinamika politik yang dimaksud adalah bagaimana aktor-aktor yang terlibat dalam pengelolaan kawasan Karst SangkulirangMangkalihat mendayagunakan sumber daya dan kapabilitas mereka (exercise their resources and capabilities) untuk memperjuangkan kepentingan yang berbeda- beda. Perbedaan kepentingan tersebut merupakan hal yang lazim terjadi dalam dunia politik, dan konsekuensi dari itu bisa termanifestasikan dalam berbagai bentuk interaksi mulai dari kooperasi sampai pada konflik. Penelitian ini kemudian berusaha untuk melihat politik pengelolaan kawasan Karst Sangkulirang- Mangkalihat dengan lebih medalam tidak hanya dengan mengidentifikasi aktor-aktor yang terlibat serta mendeskripsikan perbedaan kepentingan yang muncul diantara aktor-aktor itu. Lebih jauh penelitian ini berupaya untuk menggambarkan strategi apa yang ditempuh oleh satu aktor (dalam hal ini NonGovernmental Organization (NGO) yang peduli akan isu-isu lingkungan di Kalimantan Timur). 
Jaringan Advokasi Tambang (Jatam) dan Wahana Lingkungan Hidup (Walhi) dipilih sebagai aktor yang mewakili NGO dalam dinamika politik pengelolaan kawasan Karst Sangkulirang- Mangkalihat Kalimantan Timur. Hal ini didasari oleh kegiatan mereka yang selalu terlibat dalam isu-isu pengelolaan kawasan Karst Sangkulirang-Mangkalihat Kalimantan Timur. Untuk itu, pada bagian ini akan disajikan deskripsi tentang langkah strategi apa yang dipilih oleh Jatam dan Walhi Kaltim dalam memperjuangkan kepentingan mereka.

Ada beberapa strategi yang dilakukan oleh Jatam dan Walhi dalam pergulatan politik pengelolaan kawasan Karst Sangkulirang-Mangkalihat Kalimantan Timur, mulai dari demonstrasi, pelaksanaan focus group discussion (FGD), melakukan seminar- seminar, menerbitkan pernyataan sikap (press release), serta kampanye baik di lapangan dan di media sosial. Meski demikian sebelum penjabaran strategi yang ditempuh oleh Jatam dan Walhi tersebut perlu dijelaskan bahwa dalam melaksanakan aksinya, kedua NGO tersebut tidak berjalan sendiri-sendiri namun memilih untuk bergabung dalam satu jaringan aktivis yang sama-sama memiliki kepedulian terhadap isu pengelolaan kawasan Karst Sangkulirang-Mangkalihat Kalimantan Timur ini. Jaringan tersebut dinamakan dengan Aliansi Masyarakat Peduli Karst Kaltim atau disingkat AMPK. Keanggotaan AMPK ini mencakup NGO seperti Jatam dan Walhi, organisasi mahasiswa, masyarakat yang hidup di kawasan Karst Sangkulirang-Mangkalihat, dan masyarakat lain yang turut 
memperhatikan isu ini. Oleh sebab itu, aksi-aksi yang dilakukan Jatam dan Walhi terutama dalam bentuk demonstrasi dan aksi-aksi massa lainnya kebanyakan mengatasnamakan AMPK. Meski demikian dalam beberapa strategi khususnya kampanye dan advokasi di media daring, Jatam dan Walhi memiliki situs mereka masing-masing dan kegiatan tersebut dilakukan dengan membawa bendera organisasi mereka masing-masing (Walhi \& Jatam, 2018).

Walhi Kaltim lebih mengedepankan laporan-laporan ilmiah yang berkaitan dengan dampak kerusakan karst terhadap kehidupan sampai pada inisiasi tagline atau slogan : "Jaga Karst, Jaga Kehidupan" yang menjadi slogan strategi mereka di beberapa provinsi termasuk provinsi Kalimantan Timur. Selain itu penguatan kapasitas masyarakat setempat juga turut dilakukan oleh anggota Walhi untuk memastikan bahwa masyarakat setempat memiliki kemampuan untuk memperjuangkan kepentingan mereka sendiri ketika berhadapan dengan pemerintah dan korporasi yang bertujuan untuk mengeksploitasi karst dan mengganggu ekosistem setempat. Kampanye-kampanye juga dilakukan dengan mengekspos dampak negatif yang dirasakan oleh masyarakat yang tinggal di daerah eksploitasi karst. Sedangkan dalam ranah legal formal, Walhi aktif dalam menggugat Peraturan Daerah Nomor 1 Tahun 2016 tentang Rencana Tata Ruang Wilayah Provinsi KalimantanTimur 2016-2036.

Adapun untuk Jatam, berdasarkan informasi yang digali dalam wawancara dengan Pradarman Rupang, 
Koordinator Jatam Provinsi Kalimantan Timur ditemukan bahwa dalam beberapa hal strategi Jatam Kaltim serupa dengan apa yang dilakukan oleh Walhi, yakni dengan aktif melakukan diskusi, seminar serta edukasi terkait dengan karst dengan segala potensi yang dikandungnya, baik secar aekonomi maupun untuk keberlangsungan lingkungan hidup yang sehat. Advokasi untuk menolak penambangan karst juga dilakukan untuk menyadarkan masyarakat bahwa penambangan dan kegiatan ekstraktif lainnya yang ada di kawasan Karst Sangkulirang-Mangkalihat lebih banyak membawa dampak negatif ketimbang dampak positifnya. Perbedaannya adalah Jatam kemudian berupaya untuk menyampaikan informasi tentang apa yang mereka anggap "kebohongan" pihak pemerintah Kalimantan Timur yang berkata bahwa terjadi krisis semen yang sangat vital bagi pertumbuhan ekonomi terutama pada pertumbuhan sektor infrastruktur. Hal lainnya yang dilakukan oleh Jatam adalah dengan melakukan hearing dan membawa hasil dengar pendapat kepada Kementerian Kelautan dan Perikanan Republik Indonesia terkait dengan Rancangan Peraturan Daerah Kaltim mengenai Rencana Zonasi Wilayah Pesisir dan Pulau-Pulau Kecil (RZWP3K).

Setidaknya ada beberapa strategi yang bisa kita identifikasi sebagai instrumen Jatam dan Walhi dalam memperjuangkan kepentingan mereka dalam politik pengelolaan kawasan Karst Sangkulirang-Mangkalihat yakni:

1) Demonstrasi; 2) Seminar/FGD; dan 3) Kampanye. 


\section{Demonstrasi}

Dari sekian strategi yang bisa diidentifikasi, mungkin strategi inilah yang paling bisa dilihat dan diketahui oleh masyarakat luas. Demonstrasi memang merupakan instrumen yang selalu digunakan oleh NGO untuk memperjuangkan kepentingan mereka. Bagi Jatam dan Walhi Kaltim sebagaimana yang telah dijelaskan sebelumnya, mereka tidak melakukan aksi demonstrasi untuk menentang ekploitasi kawasan Karst Sangkulirang-Mangkalihat ini sendiri, namun mereka menggabungkan diri dengan suatu jaringan besar yang terdiri dari NGO pemerhati lingkungan, organisasi kemahasiswaan, organisasi lokal dan masyarakat umum yang turut peduli dengan isu eksploitasi Karst Sangkulirang-Mangkalihat. Dalam demonstrasi yang mereka lakukan, hampir selalu diisi dengan orasi-orasi yang mencoba untuk meyakinkan masyarakat luas khususnya masyarakat Kalimantan Timur akan bahaya ekploitasi kawasan Karst Sangkulirang-Mangkalihat. Orasi-orasi ini biasanya dilakukan di tempat-tempat strategis dan pusat pemerintahan Provinsi Kalimantan Timur seperti Kantor Gubernur, Gedung Dewan Perwakilan Rakyat Daerah, dan titik-titik strategis lainnya.

Selain orasi-orasi yang selalu disampaikan oleh demonstran, aksi-aksi teatrikal dan kesenian lainnya juga kerap dilakukan sebagai instrumen propaganda. Aksi-aksi tersebut mencoba untuk menggambarkan betapa kerusakan kawasan Karst Sangkuliran-Mangkalihat ini lebih banyak mendatangkan dampak negatif bukan hanya untuk 
masyarakat yang hidup di sekitar kawasan tersebut namun juga bagi Kalimantan Timur, Indonesia dan Dunia. Hal ini disebabkan pentingnya ekosistem Karst bagi siklus air bersih dan ekosistem penunjang kehidupan flora dan fauna secara keseluruhan.

Tidak jarang demonstrasi yang mereka lakukan berujung pada kontak fisik dengan pihak kepolisian dan satuan keamanan lainnya. Meski demikian, mereka mengakui bahwa hal tersebut merupakan suatu yang lumrah dan mereka sadar akan potensi bentrokan yang terjadi. Keberanian itu muncul karena mereka percaya bahwa mengungkapkan pendapat di muka umum merupakan hak tiap-tiap warga negara yang dijamin dalam konstitusi.

Ada beberapa demonstrasi penolakan eksploitasi kawasan Karst Sangkulirang-Mangkalihat yang sudah mereka lakukan sejak tahun 2016. Setidaknya menurut informasi langsung yang didapatkan telah dilakukan empat kali demonstrasi besar oleh AMPK Kalimantan Timur yakni: 1) Tanggal 26 Oktober 2016 di depan Kantor Gubernur Provinsi Kalimantan Timur, 2) Tanggal 28 Oktober 2016 di depan Gedung Dewan Perwakilan Rakyat Daerah Provinsi Kalimantan Timur, 3) Tanggal 22 Desember 2016 di depan Kantor Gubernur Provinsi Kalimantan Timur yang sekaligus bertepatan dengan Hari Ibu, dan 4) Tanggal 17 November 2017 di depan Kantor Gubernur Provinsi Kalimantan Timur yang juga bertepatan dengan International Student Day.

\section{Seminar/FocusGroup Discussion}


Selain melakukan aksi-aksi demonstrasi, Jatam dan Walhi juga aktif dalam kegiatan seminar, diskusi dan FGD yang diadakan oleh mereka sendiri maupun diadakan oleh lembaga-lembaga lain. Seperti Focus Group Discussion yang bertemakan "Policy Brief Mendorong Penyelamatan Karst Indonesia” yang diadakan di Fakultas Hukum Universitas Mulawarman pada tanggal 17 Februari 2017. Perwakilan dari Walhi dan Jatam hadir pada acara tersebut untuk memberikan masukan terhadap draft Polic Brief yang berjudul "Melindungi Karst, Melindungi Kehidupan, Mendorong Kebijakan Negara terhadap Perlindungan Kawasan Karst Indonesia".

Dalam FGD yang diselenggarakan oleh Fakultas Hukum Universitas Mulawarman dan Tim Kerja Perempuan dan Tambang (TKPT) Kalimantan Timur, perwakilan dari Walhi dan Jatam berbagi informasi mengenai data-data penting terkait logika pendirian pabrik semen di Kalimantan Timur. Mereka sepakat bahwa pada kenyataannya, kondisi krisis semen sebagaimana yang dikatakan oleh pemerintah daerah tidaklah benar adanya. Mereka juga membantah argumen pemerintah daerah yang mengatakan bahwa Provinsi Kalimantan Timur membutuhkan banyak semen untuk mendorong pertumbuhan. Kondisi di lapangan menunjukkan bahwa Kalimantan Timur justru mengalami surplus persediaan semen, selain itu pembangunan fisik dan eksploitatif mereka nilai sangat tidak tepat untuk diterapkan di Kalimantan Timur yang sudah sekian lama merasakan 
dampak buruk dari pembangunan dan industri eksploitatif.

Jatam dan Walhi juga aktif dalam melakukan seminarseminar yang kebanyakan bersifat non-formal yakni dengan berbincang dan berdiskusi dengan masyarakat umum dan mahasiswa terkait dengan isu eksploitasi karst. Diskusidiskusi informal semacam ini seringkali dilakukan secara spontan di manapun ada kesempatan untuk melakukannya. "Militansi" semacam ini dilakukan karena mereka percaya bahwa semakin banyak masyarakat yang mengetahui faktafakta tentang eksploitasi karst, maka masyarakat akan sadar akan dampak negatif yang dibawa.

\section{Kampanye}

Selain melakukan demonstrasi dan seminar/FGD, Jatam dan Walhi juga aktif dalam melakukan kampanye yang berisikan ajakan untuk melestarikan karst dan menolak segala bentuk eksploitasi di sekitar kawasan karst. Kampanye yang mereka lakukan lebih banyak terekam secara daring (online) dalam situs resmi mereka masing-masing seperti gambargambar dibawah ini:

Gambar 3. Kampanye Jatam Save the Karst Save the Future 

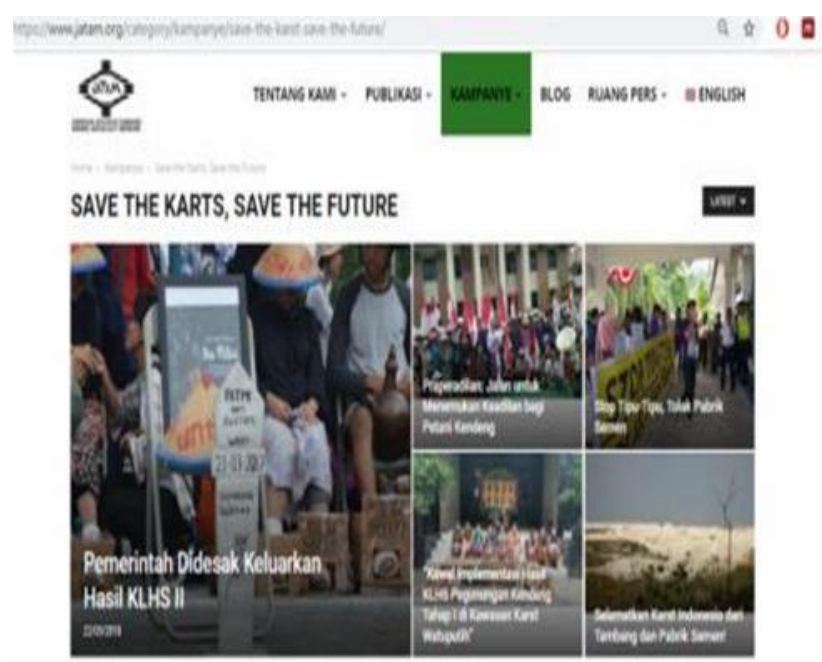

I Tenturit

Sumber: https://www.jatam.org/category/kampanye/save-thekarst-save-the-future/

Gambar 4. Kampanye Walhi

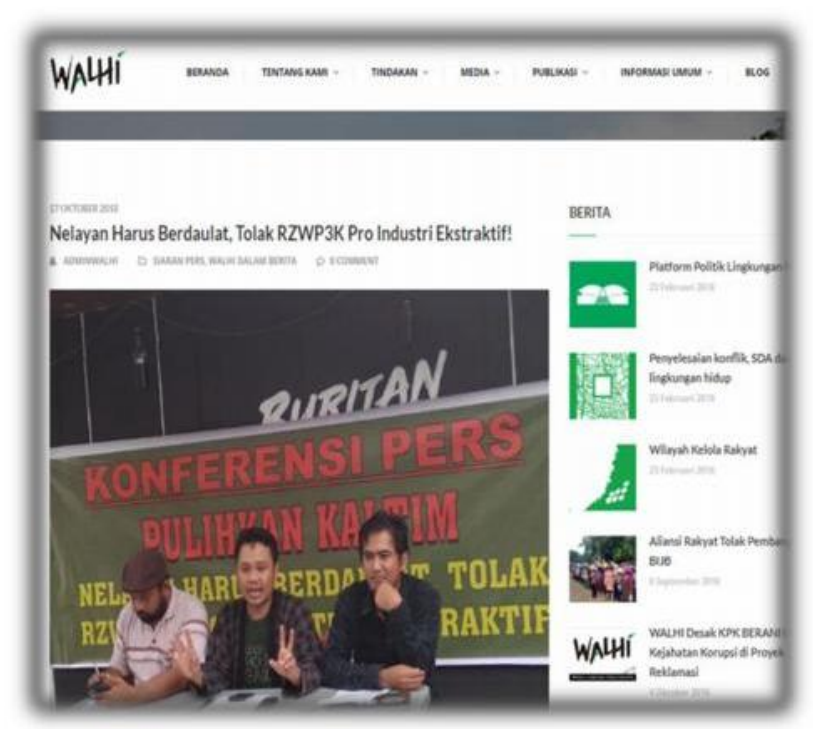

Sumber: https://walhi.or.id/nelayan-harus-berdaulat-tolak-rzwp3k- 
pro-industri-ekstraktif/

Dalam situs resminya, konten-konten yang berisikan ajakan dan kecaman terhadap pemerintah yang dinilai melegalkan ekploitasi kawasan karst dan gagal melindungi kawasan tersebut mereka kumpulkan dalam satu section khusus berjudul "kampanye" sehingga bisa dilihat dengan jelas pesan-pesan yang ingin mereka sampaikan dalam setiap artikel. Substansi dari artikel-artikel itu berisikan informasi yang rinci tentang kondisi karst baik di kawasan Karst Sangkulirang-Mangkalihat maupun kawasan karst lainnya di Indonesia serta ancaman-ancaman yang dihadapi oleh ekosistem karst tersebut.

\section{Penutup}

Tulisan ini berupaya untuk melihat bagaimana upaya dan cara yang dilakukan oleh NGO untuk melindungi kawasan karst Sangkulirang-Mangkalihat. Hal ini menarik untuk diteliti karena dalam kajian tentang NGO dan gerakan sosial, karakteristik NGO serta kapabilitas yang mereka miliki mempengaruhi formulasi kepentingan mereka. Selain itu juga mempengaruhi bagaimana cara yang mereka tempuh untuk mencapai tujuan tersebut. Cara dan upaya yang dilakukan sangat beragam mulai dari cara-cara nirkekerasan sampai pada konflik fisik.

Upaya-upaya tersebut juga tidak terlepas dari konteks 
sosial dan politik di arena mereka beroperasi sehingga menarik untuk diperdalam bagaimana karakteristik serta kapabilitas NGO yang memperjuangkan kelestarian karst Sangkulirang-Mangkalihat serta konteks sosial-politik yang ada di Kalimantan Timur yang pada gilirannya berpengaruh terhadap cara yang ditempuh NGO tersebut dalam memperjuangkan kepentingan mereka.

Dari hasil observasi serta wawancara mendalam dengan Direktur Walhi dan Koordinator Jatam Kalimantan Timur setidaknya ada beberapa strategi yang bias diidentifikasi sebagai instrumen Jatam dan Walhi dalam memperjuangkan kepentingan mereka dalam politik pengelolaan kawasan Karst Sangkulirang-Mangkalihat yakni :1) Demonstrasi; 2) Seminar/FGD; dan 3) Kampanye. Jatam dan Walhi dalam menjalankan aksinya tidak berjalan sendirisendiri, terutama dalam aksi-aksi demonstrasi yang mereka lakukan. Mereka melakukan aksinya dengan mengatasnamakan Aliansi Masyarakat Peduli Karst (AMPK) Kalimantan Timur. Dalam jaringan AMPK bukan hanya Jatam dan Walhi yang tergabung didalamnya namun juga organisasi kepemudaan dan organisasi masyarakat lainnya. 


\section{DAFTAR PUSTAKA}

Buku, Jurnal dan Artikel

Betsill, Michele M. dan Elisabeth Corell. 2008. "Introduction to NGO Diplomacy" dalam Michele M. Betsill dan Elisabeth Corell, NGO Diplomacy: The Influence of Nongovernmental Organizations in International Relations, MIT Press, Massachusetts.

Brown, L. David, Alnoor Ebrahim and Srilatha Batliwala. 2011. "Governing International Advocacy NGOs". World Development. No. 06 Vol. 40. p.1098-1108

Kurniawan, Nanang Indra. 2012. "Wacana Lingkungan dan Pembangunan Berkelanjutan Dalam Lembaga Swadaya Masyarakat di Indonesia", JSP, Fisip UGM, Vol. 16, No. 1 Juli, h.1-15

Marshall, Andrew, J. et.al. 2017, "Use of Limestone Karst Forests by Bornean Orangutans (Pongo pygmaeus morio) in the Sangkulirang Peninsula, East Kalimantan, Indonesia", American Journal of Primatology, Vol. 69, p. 212-219

Salas, L. A. et,al. 2005. "Biodiversity, endemism and the conservation of limestone Karsts in the Sangkulirang Peninsula, Borneo",Biodiversity,Vol. 6, No. 2, p. $15-23$

The Nature Conservancy, mengapa karst sangkulirang-Mangkalihat penting? dalam https://www.nature.or.id/publikasi/laporan-tahunan-danisu-umum-konservasi/karst-sangkulirang-mangkalihat.pdf diakses pada 12 September 2018. 
Widyaningsih, Grita $\quad 2017$. "Permasal than Hukum dalam Perlindungan Ekosistem Karst di Indonesia (Studi Kasus: Ekosistem Karst Sangkulirang-Mangkalihat, Provinsi Kalimantan Timur)", Jurnal Hukum Lingkungan, Vol. 3, Issue 2, Maret, h. 73-95

Wawancara

Wawancara dengan Direktur Wahana Lingkungan Hidup (Walhi) Kalimantan Timur, Fathur Roziqin Zen pada tanggal 22 Oktober 2018 bertempat di Sekretariat Walhi, Samarinda.

Wawancara dengan Koordinator Jaringan Advokasi Tambang (Jatam) Kalimantan Timur, Pradirman Rupang pada tanggal 23 Oktober 2018 bertempat di Sekretariat Walhi, Samarinda. 